\title{
Pengembangan Soft Skill Guru SD melalui Pelatihan Aplikasi Perkantoran dan Desain Grafis di Polewali Mandar
}

\author{
Suryani ${ }^{*}$, Arwansyah $^{1}{ }^{1}$ Hasyrif $^{1}$ \\ ${ }^{1}$ Teknik Informatika, STMIK Dipanegara, Jl. Perintis Kemerdekaan No.KM.9, Tamalanrea Indah, Kec. Tamalanrea,
} Kota Makassar, Sulawesi Selatan, Indonesia 90245

*Email koresponden: suryani187@dipanegara.ac.id

\section{ARTICLE INFO}

\section{Article history}

Received: 17 Jul 2020

Accepted: 26 Jan 2021

Published: 23 Apr 2021

\section{Kata kunci:}

Aplikasi Perkantoran

Bahan Ajar

Desain Grafis

Soft Skill

\begin{abstract}
A B S T R A K
Background: SDN 15 Tonyaman Polewali Mandar merupakan salah satu Sekolah Dasar Negeri yang memiliki permasalahan antara lain rendahnya mutu dari SDM pengelola pendidikan yang bisa menghambat keberlangsungan proses pendidikan yang berkualitas. Hampir semua guru di SDN 15 Tonyaman memiliki komputer/laptop, namum pemahaman terkait Ilmu komputer khususnya dalam penggunaan aplikasi perkantoran yang digunakan sebagai tools untuk mebuat bahan ajar dan juga memberikan materi ajar kepada siswa sangatlah minim. Guru-guru di sekolah tersebut masih menggunakan cara manual dalam menyajikan materi pembelajaran, menginput data siswa, nilai siswa, dan data adminstratif lainnya. Metode: Metode yang digunakan adalah dengan pelatihan aplikasi perkantoran dengan memanfaatkan Ms. Office Word, Excel dan Power Point. Hasil: Dengan pelatihan aplikasi perkantoran dan desain grafis, dapat melakukan sinkronisasi terhadap berbagai program peningkatan kualitas pendidikan. Kesimpulan: memberi kemudahan dalam menyelesaikan pekerjaan administratif, meningkatkan kreatifitas guru dalam menciptakan bahan ajar yang lebih kreatif dan inovatif.
\end{abstract}

\section{A B S T R A C T}

Background: SDN 15 Tonyaman Polewali Mandar is one of the state elementary schools which has problems, including the low quality of human resources managing education which can hinder the continuity of the quality education process. Almost all teachers at SDN 15 Tonyaman have a computer/laptop, but an understanding of computer science, especially in the use of office applications, is used as a tool for making teaching materials and also providing teaching materials to students. The teachers in these schools still use manual methods in presenting learning materials, inputting student data, student scores, and other administrative data. Methods: The method used is to provide office application training by utilizing Ms. Office Word, Excel, and PowerPoint. Results: By providing training in office applications and graphic design, it can synchronize various programs to improve the quality of education. Conclusions: provide convenience in completing administrative work, increase teacher creativity in creating more creative and innovative teaching materials

(C) 2021 by authors. Lisensi Jurnal Solma, UHAMKA, Jakarta. Artikel ini bersifat open access yang didistribusikan di bawah syarat dan ketentuan Creative Commons Attribution (CC-BY) license.

\section{PENDAHULUAN}

Di era revolusi industry 4.0 ini peranan IT semakin penting karena hampir semua pekerjaan dilakukan secara digital. Kesadaran menggunakan IT untuk kepentingan yang positif yang seharusnya dibarengi dengan update pengetahuan seiring dengan perkembangan IT di Indonesia (Rusman, 2012). Perkembangan teknologi yang terjadi begitu cepat telah merubah hampir seluruh tatanan kehidupan sosial, mulai dari kegiatan ekonomi dengan penggunaan uang elektrik untuk melakukan transaksi (e-payment), pemanfaatan aplikasi online untuk berbelanja, 
order makanan, transportasi dan kebutuhan lainnya, sampai pada pemanfaatan teknologi di bidang pendidikan, papan tulis mulai digantikan dengan koputer/laptop atau handphone yang diproyeksikan ke layar putih menggunakan proyektor (Harahap, 2019). Materi atau bahan ajar dibuat dan disajikan melalui komputer atau handphone secara kreatif dan inovatif. Tidak hanya bahan ajar, semua kegiatan perkantoran seperti input data siswa, nilai siswa, dan data adminstratif lainnya tidak lagi diolah secara manual sehingga menghidari penggunaan kertas yang berlebihan (paperless). Media pembelajaran berbasis teknologi sangat efektif, efisien, dan mengutamakan kemandirian siswa-siswi, sehingga guru dan murid bisa lebih interaktif (Syah, Arirdha Zikra, 2018).

Guru dikenal sebagai penentu kemajuan dan keberhasilan pada bidang pendidikan (ujung tombak pendidikan). Guru terjun secara langsung berinteraksi dengan siswa-siswi di ruang kelas untuk mencapai tujuan pembelajaran. Oleh sebab itu kualitas dan mutu guru-guru harus dikembangkan demi kelangsungan pendidikan yang berkualitas. Salah satunya dengan pengembangan softskill yang diiliki oleh guru-guru (Azuka, 2018).

Peningkatan kualitas softskill tenaga pendidik sangat dipengaruhi oleh teknologi pendidikan. Pendidikan berbasis teknologi mengambil peranan penting dalam mendidik, melatih, dan mengembangkan SDM yang berkualitas (Budiarto, 2019).

Berdasarkan wawancara yang dilakukan dengan kepala sekolah SDN 15 Tonyaman Polewali mandar dikemukakan bahwa pemahaman tentang Ilmu Pengetahuan dan Teknologi yaitu dalam penggunaan komputer khususnya aplikasi perkantoran dan desain grafis masih sangat minim, Meskipun hampir semua Guru memiliki computer/laptop, akan tetapi mereka masih menggunakan papan tulis sebagai media pembelajaran, mebuat bahan ajar dan menyajikan materi ajar kepada siswa-siswi secara manual. Update ilmu tidak dilakukan, sehingga menguras banyak waktu dan energi mencatat di papan tulis kemudian menjelaskan materi, menghapus, mencatat lagi lalu menjelaskan lagi. Selain itu kreatifitas guru dalam menyajikan materi menjadi monoton dan tidak berkembang (Astagani \& Triyono, 2018).

Oleh karena itu solusi yang lebih spesifik ditawarkan untuk mengatasi permasalah tersebut adalah:

1.Memberikan Materi tentang aplikasi perkantoran dan desain grafis.

2.Menjelaskan tentang fitur-fitur dan penggunaan Ms. Office Word, Excel dan Power Point sebagai bagian dari aplikasi perkantoran.

3.Menjelaskan tentang desain grafis dalam menyajikan materi yang lebih interaktif.

4.Mendemonstrasikan cara membuat, mendesain dan menyajikan bahan ajar, e-modul, menginput data nilai siswa dan data administratif lainnya

Tujuan dari kegiatan pengabdian adalah peningkatan keterampilan bagi guru tentang pemanfaatan teknologi untuk menjamin kualitas pembelajaran. Selain itu mengasah keterampilan guru dalam membuat dan menyajikan bahan ajar secara kreatif, inovatif dan lebih interaktif.

\section{MASALAH}

Berdasarkan wawancara yang dilakukan dengan kepala sekolah SDN 15 Tonyaman Polewali mandar dikemukakan bahwa pemahaman tentang Ilmu Pengetahuan dan Teknologi yaitu dalam penggunaan komputer khususnya aplikasi perkantoran dan desain grafis masih sangat minim. Meskipun hampir semua Guru memiliki computer/laptop, akan tetapi mereka masih menggunakan papan tulis sebagai media pembelajaran, mebuat bahan ajar dan menyajikan materi ajar kepada siswa-siswi secara manual. Update ilmu tidak dilakukan, sehingga menguras banyak waktu dan energi mencatat di papan tulis kemudian menjelaskan materi, menghapus, 
mencatat lagi lalu menjelaskan lagi. Selain itu kreatifitas guru dalam menyajikan materi menjadi monoton dan tidak berkembang.

Rumusan permasalahan adalah sebagai berikut:

1. Bagaimana meningkatkan softskill guru dalam bidang IT ?

2. Bagaimana mengimplementasikan aplikasi perkantoran dalam berbagai kegiatan administratif sekolah termasuk membuat dan menyajikan bahan ajar secara kreatif dan inovatif?

3. Bagaimana mengimplementasikan desain grafis untuk media pembelajaran yang lebih interaktif?

\section{METODE PELAKSANAAN}

Metode pelaksanaan pengabdian masyarakat dilakukan dalam mengatasi masalah dari mitra adalah sebagai berikut :

1. Memberikan materi tentang aplikasi perkantoran dan desain grafis.

2. Menjelaskan tentang fitur-fitur dan penggunaan Ms. Office Word (Jarot et al., 2012), Excel dan Power Point sebagai bagian dari aplikasi perkantoran.

3. Menjelaskan tentang desain grafis dalam menyajikan materi yang lebih interaktif.

4. Mendemonstrasikan cara membuat, mendesain dan menyajikan bahan ajar, e-modul, menginput data nilai siswa dan data administratif lainnya.

Kegiatan Pengabdian Masyarakat dilaksanakan pada SD Negeri 15 yang beralamat di JL. Tonyaman, Anreapi, Polewali, Kabupaten Polewali Mandar, Sulawesi Barat. Tahapan Pengabdian kegiatan dilakukan selama 2 bulan Yakni Juni-Juli 2020, dimulai dari tahap survei lokasi dan perizinan kegiatan, Pembuatan Bahan Ajar (Modul), Pelaksanaan kegiatan yang dilaksanakan selama 3 (tiga) hari yaitu tanggal 3-5 Juli 2020 setiap pukul 08.00 - 12.00 Wita.

Kegiatan pengabdian dilaksanakan dalam beberapa tahap, meliputi;

1. Tahap Persiapan

Tahap persiapan yang dilakukan untuk melaksanakan program ini meliputi;

a. Survei tempat pelaksanaan kegiatan dan menyelesaikan administrasi perijinan pada SD Negeri 15 Tonyaman yang akan menjadi mitra pada pelaksanaan pengabdian masyarakat.

b. Pembuatan modul pelatihan yang akan dibagikan pada para peserta saat pelatihan berlangsung.

c. Memperbanyak modul dan membuatan spanduk kegiatan.

2. Tahap Pelaksanaan Kegiatan

Dalam kegiatan pengabdian, tim pelaksana melakukan 4 (empat) metode pelaksanaan yakni Pelatihan, Diskusi, Bimbingan dan Evaluasi.

a. Pelatihan dimaknai sebagai proses pemberian pengetahuan dan pemahaman kepada para Guru mengenai aplikasi perkantoran, fitur-fitur, implementasi dan desain grafis dalam menyajikan materi.

b. Diskusi dimaknai sebagai upaya pengembangan keterampilan yang kreatif, inovatif dan iteraktif para Guru dalam implementasi aplikasi perkantoran dan desain grafis.

c. Bimbingan dimaknai sebagai kegiatan pembentukan dan pembinaan kepada para Guru, sehingga memiliki keterampilan dalam memanfaatkan teknologi di setiat kegiatan administratif sekolah.

d. Evaluasi dimaknai sebagai pengawasan dan penilaian atas pelaksanaan penggunaan aplikasi perkantoran dan desain grafis. 


\section{HASIL DAN PEMBAHASAN}

Kegiatan pengabdian masyarakat dilaksanakan selama 3 (tiga) hari pada tanggal 3-5 juli 2020. Hasil Evaluasi peserta diberikan tugas untuk membuat sebuah bahan ajar yang terdiri dari beberapa slide (minimal 5 slide) dengan mengimplementasikan materi yang sudah didapatkan, yakni memanfaatkan fitur-fitur power point untuk desain grafis agar bahan ajar lebih interaktif dan lebih menarik yang meliputi implementasi animation effects, apply a motion path, menambah obyek, memberi efek, transitions, membuat action buttons dan juga hyperlink (Dewandaru, 2013). Setelah selesai mengerjakan bahan ajar, peserta memperlihatkan slide yg sudah didesain kepada instruktur (Mulyana, I. et al., 2019).

Hasil evaluasi pencapaian materi yang diberikan dalam kegiatan pengabdian dapat dilihat pada tabel 1.

Tabel 1. Tingkat Pencapaian Materi

\begin{tabular}{lllll}
\hline \multicolumn{1}{c}{ Jenis Kegiatan } & Mampu & $\begin{array}{c}\text { Kurang } \\
\text { Mampu }\end{array}$ & $\begin{array}{c}\text { Belum } \\
\text { Mampu }\end{array}$ & $\begin{array}{c}\text { Total } \\
\text { Peserta }\end{array}$ \\
\hline Membuat Bahan Ajar & 19 & 0 & 0 & 19 \\
Mendistribusikan Materi & 14 & 5 & 0 & 19 \\
Implementasi fitur Ms. Word & 17 & 2 & 0 & 19 \\
Implementasi fitur-fitur Ms. Excel & 15 & 4 & 0 & 19 \\
Implementasi fitur-fitur Ms. & & & & 19 \\
Powerpoint & 14 & 5 & 0 & \\
\hline
\end{tabular}

Seluruh peserta pelatihan Pengembangan Soft Skill Guru-Guru Melalui Pelatihan Aplikasi Perkantoran Dan Desain Grafis SDN 15 Tonyaman Polewali Mandar sangat antusias dalam mengikuti pelatihan yang diberikan oleh Instruktur (Parmin \& Peniati., 2012). Seluruh peserta mengikuti pelatihan mulai dari hari pertama hingga penutupan. Peserta sangat aktif bertanya. Pada saat Evaluasi pembuatan bahan ajar, semua peserta dapat membuat bahan ajar sesuai dengan permintaan instruktur. Seluruh peserta dapat mendistribusikan materi yang dimiliki ke dalam bentuk bahan ajar yang lebih interaktif, meskipun terdapat 5 peserta yang masih dibantu oleh tim pengabdian. Pada kegiatan pembuatan bahan ajar semua peserta sudah mulai mampu mengimplementasikan fitur-fitur ms.word, meskipun ada 2 peserta yang masih bingung karena lupa dengan materi yang sudah didapatkan(Zondra, 2018). Berbeda dengan implementasi fiturfitur ms.excel, ada 4 peserta yang mengaku masih kesulitan, alasannya karena belum terbiasa. Sedangkan implementasi fitur-fitur ms.pow er point, ada 14 peserta sudah mampu meskipun butuh waktu yang agak lama, dan 5 lainnya masih butuh bimbingan dalam implementasi fiturfitur power point untuk membuat bahan ajar yang interaktif (Sulindawati \& Se, 2016).

1. Hasil Kuesioner

Untuk mengukur tingkat pencapaian pengabdian masyarakat, dibuat kuesioner yang ditujukan pada peserta pengabdian dan dibagikan pada 19 guru dengan pertanyaan berikut : 
a. Apakah sebelum pelatihan anda sudah mengenal aplikasi perkantoran seperti Ms. Word, Excel dan Powerpoint?

b. Apakah sebelum pelatihan anda sudah mengimplementasikan aplikasi perkantoran seperti Ms. Word, Excel dan Powerpoint?

c. Apakah bahan ajar disajikan menggunakan power point kepada peserta didik? Jika Tidak, Bagaimana penyajian materi di kelas?

d. Menurut anda, apakah penyajian materi yang digunakan selama ini memudahkan guru dalam memberi pemahaman kepada peserta didik? Jika Tidak, Kenapa?

e. Menurut anda apakah aplikasi perkantoran dan desain grafis menarik? kemukakan pendapat anda.

f. Menurut anda apakah materi tentang aplikasi perkantoran dan desain grafis Mudah dipahami dan diimplementasikan?

g. Apakah anda tertarik mengimplementasikan bahan ajar interaktif?

Hasil persentase kuesioner yang ditanggapi oleh peserta pelatihan digambarkan melalui beberapa diagram.

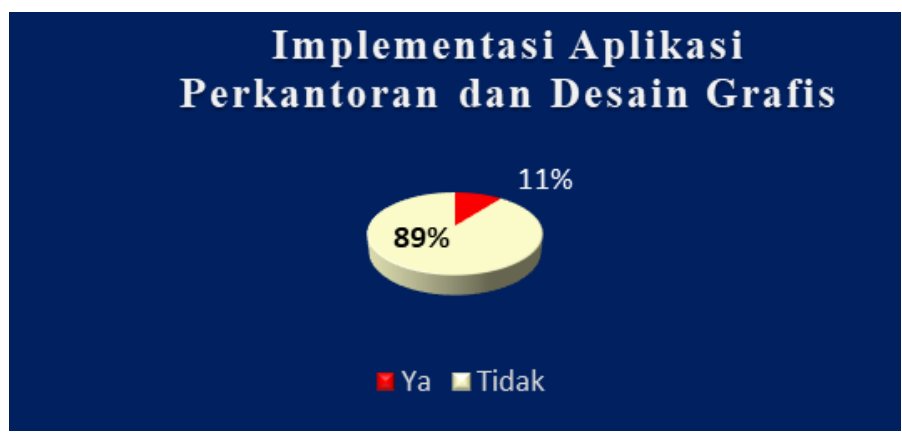

Gambar 1. Implementasi

Gambar 1 menunjukkan $11 \%$ peserta menyatakan sudah pernah mengimplementasikan aplikasi perkantoran dan desain grafis dalam proses pembelajaran dan $89 \%$ peserta menyatakan tidak pernah. Selama ini pembelajaran dilakukan secara manual dan tatap muka secara langsung.

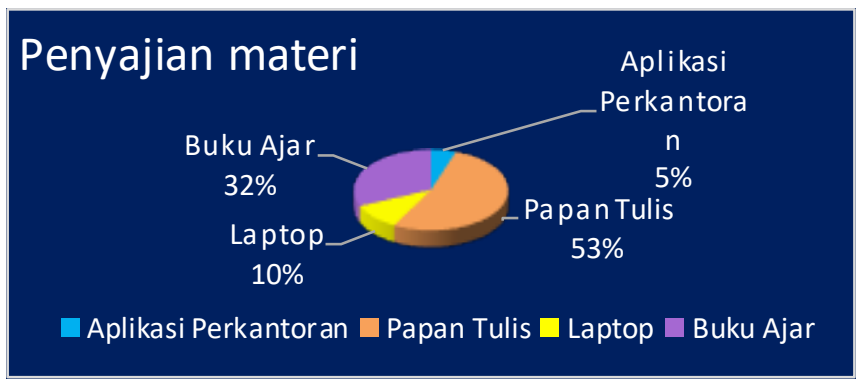

Gambar 2. Penyajian Materi Ajar

Gambar 2 menunjukkan $5 \%$ peserta sebelum pelatihan sesekali menyajikan materi ajar menggunakan aplikasi perkantoran, selebihnya $32 \%$ menggunakan buku ajar, $10 \%$ menggunakan laptop sebagai e-book dan 53 \% masih mencatat materi di papan tulis lalu kemudian dijelaskan. 


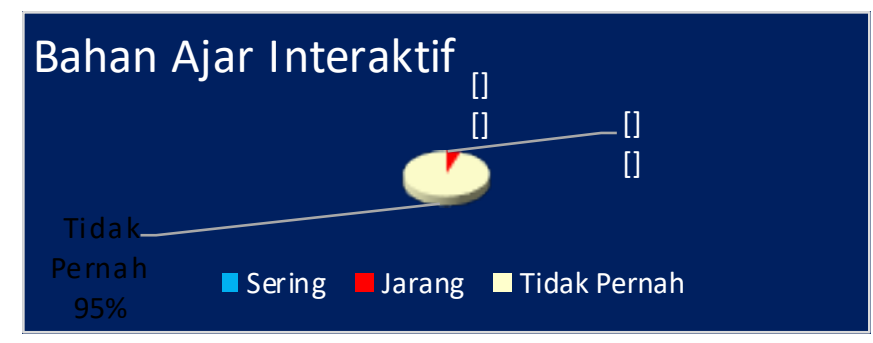

Gambar 3. Penggunaan Bahan Ajar Interaktif

Gambar 3 menunjukkan $95 \%$ peserta menyatakan tidak pernah menggunakan power point sebagai media pembelajaran yang interaktif dan $5 \%$ peserta menyatakan pernah tapi jarang digunakan. Hampir semua peserta menyatakan bahwa mereka belum tau bagaimana menyajikan materi sehingga lebih interaktif dan menambah minat belajar peserta didik.

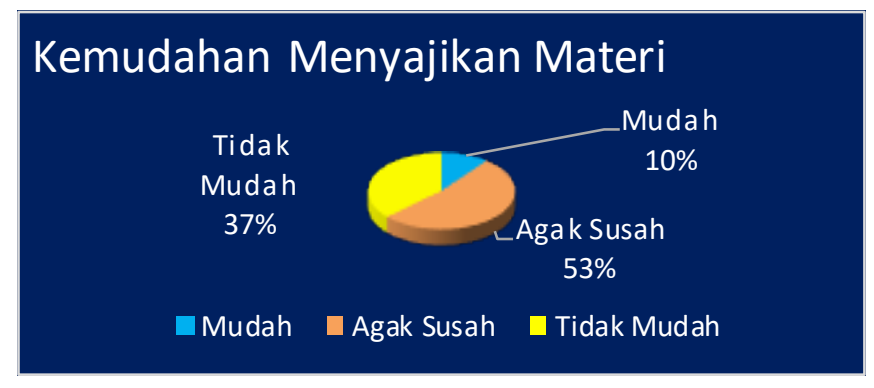

Gambar 4. Penyajian Materi Sebelum Pelatihan

Gambar 4 menunjukkan bahwa penyajian materi ajar selama ini tidak memberi ruang bagi peserta untuk berkreasi menyajikan bahan ajar yang lebih mudah dan lebih interaktif.

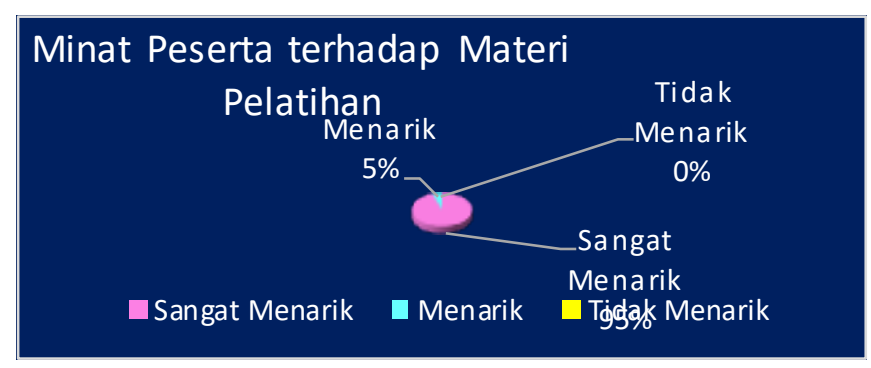

Gambar 5. Minat peserta

Gambar 5 menunjukkan minat peserta terhadap materi pelatihan $95 \%$ sangat menarik dan 5 $\%$ menarik. Para peserta pelatihan sangat antusias mengikuti pelatihan, mereka pun mengakui bahwa dengan mengikuti pelatihan menjadi semangat baru dan bekal agar memudahkan para pendidik maupun peserta didik dalam proses belajar mengajar di sekolah. 


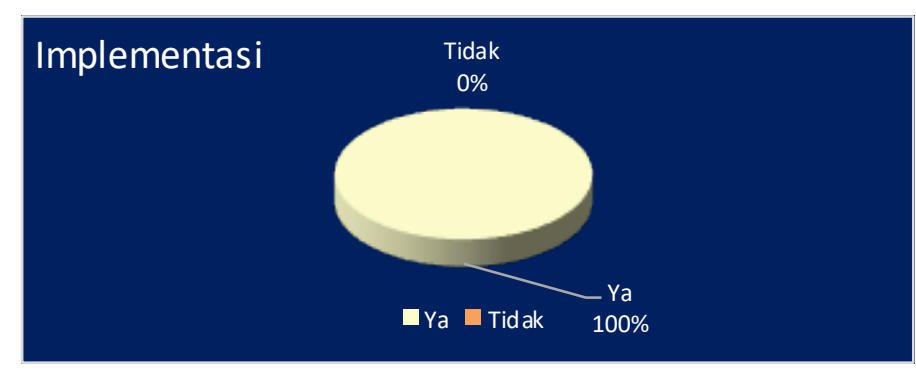

Gambar 6. Minat Implementasi

Gambar 6 menunjukkan minat peserta setelah mengikuti pelatihan. Semua pesarta merasa perlu dan sangat tertarik mengimplementasikan aplikasi perkantoran dan desain grafis dalam membuat bahan ajar, menghitung dan menyimpan nilai peserta didik maupun keperluan administratif sekolah lainnya.

Adapun tingkat kesulitan pelaksanaan kegiatan pengabdian masyarakat tergolong sulit, hal tersebut disebabkan oleh peserta pelatihan dalam hal ini adalah guru yang hampir semua masih belum mahir dalam menggunakan komputer ataupun laptop (Lee, 2017). Oleh sebab itu dilakukan pembekalan dan pendampingan untuk memudahkan pelaksanaan kegiatan

\section{KESIMPULAN}

Pelaksanaan Pengabdian Masyarakat Yaitu Pengembangan Soft Skill Guru-Guru Melalui Pelatihan Aplikasi Perkantoran Dan Desain Grafis Di Sdn 15 Tonyaman Polewali Mandar Dapat Memberikan Pengetahuan Kepada Guru-Guru Tentang Fitur-Fitur Dalam Ms. Office Word, Excel, Power Point Dan Desain Grafis, Memudahkan Pengolahan Data Siswa Dan Kegiatan Administratif Lainnya. Selain Itu Guru-Guru Merasa Terbekali Banyak Pengetahuan Dan Termotivasi Untuk Meningkatkan Keterampilan Dalam Memanfaatkan Teknologi Untuk Membuat Dan Melakukan Pengajaran Secara Kreatif, Inovatif Dan Lebih Interaktif. Diharapkan Untuk Kegiatan Pengabdian Masyarakat Berikutnya Dapat Membekali Lebih Banyak Pengetahuan Dengan Metode Yang Lebih Efektif, Banyak Latihan Untuk Mengasah Kreatifitas Dan Berinovasi Membuat Dan Menyajikan Bahan Ajar Yang Mampu Meningkatkan Minat Belajar Dan Pemahaman Peserta Didik.

\section{UCAPAN TERIMA KASIH}

Terima kasih disampaikan kepada STMIK DIPANEGARA yang telah mendanai kegiatan pengabdian di SDN 15 Tonyaman Polewali Mandar.

\section{DAFTAR PUSTAKA}

Astagani, A., \& Triyono, A. (2018). Pengaruh Media Pembelajaran Dengan Gambar Abstrak Terhadap Motivasi Belajar Desain Grafis Siswa Smkn 7 Samarinda. Prosiding Snitt Poltekba, 3(1), 364-373.

Azuka, E. B. (2018). Powerpoint Presentation As An Alternative To Traditional Approach To Teaching Business Education Courses In Tertiary Institutions: Benefits, Challenges And Solutions. Nigerian Journal Of Business Education (Nigjbed), 3(2), 1-14.

Budiarto, S. P. (2019). Pelatihan Desain Grafis Dan Multimedia Di Sekolah Menengah Kejuruhan Persatuan Guru Republik Indonesia Banyuputih Situbondo. Jpm (Jurnal Pemberdayaan Masyarakat), 4(1), 308-313.

Dewandaru, D. S. (2013). Pemanfaatan Aplikasi E-Office Untuk Mendukung Penerapan E-Government Dalam Kegiatan Perkantoran Studi Kasus: Puslitbang Jalan Dan Jembatan. In Seminar Nasional Teknologi Informasi Dan Komunikasi. 
Harahap, L. (2019). Peran Teknologi Informasi Dan Komunikasi Dalam Pendidikan.

Jarot, S., Shenia, A., \& Sudarma, S. (2012). Buku Pintar Microsoft Office 2007 \& 2010: Word-Excel-Powerpoint. Mediakita.

Lee, C. (2017). Belajar Microsoft Powerpoint (Mahir) Step-By-Step. Elex Media Komputindo.

Mulyana, I., K., M., Putra, A. P., K., \& M., Suriansyah, M. I., \& Kom, M. (2019). Buku Ajar Desain Grafis Dan Multimedia (Vol. 1). Flash.

Parmin, \& Peniati., E. (2012). Pengembangan Modul Mata Kuliah Strategi Belajar Mengajar Ipa Berbasis Hasil Penelitian Pembelajaran. Jurnal Pendidikan Ipa Indonesia 1, 1.

Rusman. (2012). Pembelajaran Berbasis Teknologi Informasi dan Komunikasi. Rajawali Pers.

Sulindawati, N. L. G. E., \& Se, A. (2016). Pengembangan Model Pembelajaran Dalam Penyusunan Financial Statement Melalui Media Microsoft Excel. In Seminar Nasional Riset Inovatif (Vol. 4).

Syah, Arirdha Zikra, et all. (2018). Pelatihan Media Pembelajaran Interaktif Berbasis Multimedia Bagi Guru Guru SMAN 02 Tanjung Balai. Jurdimas (Jurnal Pengabdian Kepada Masyarakat), 1(1), 1-6.

Zondra, E. (2018). Pelatihan Penggunaan Program Aplikasi Microsoft Word Serta Microsoft Powerpoint Untuk Pembuatan Bahan Ajar Bagi Guru-Guru Di Madrasah Ibtidaiyah Muhammadiyah I Pekanbaru. 